\title{
DNA fingerprinting to be used for British immigrants?
}

\section{London}

THE technique of DNA fingerprinting based on restriction fragment length polymorphisms (RFLP) appears to have created a dilemma for the British Home Office, which is considering whether to use the tests for assessing applications for immigration to Britain from the Indian sub-continent.

Routine use of DNA fingerprinting in immigration cases would mean that more cases were approved and that $£ 7$ million a year in administration costs would be saved, according to a report being considered by the Home Office. In British law, resident immigrants are entitled to ask for resident status for certain relatives.

Two weeks ago, the Home Office minister responsible for immigration, $\mathrm{Mr}$ Timothy Renton, was quoted as agreeing that the test can categorically say whether or not "a person is related to the father or the mother... but not how they are related". But that is "wholly wrong", says Dr Alec Jeffreys, of Leicester University, who invented the test and helped the company Cellmark Diagnostics carry out and report on the pilot project commissioned by the Home Office.

Cellmark Diagnostics, in which the chemical manufacturer ICI plc owns a controlling interest, has exclusive rights to commercialize the DNA fingerprinting test, and has considerable experience of its application to immigration cases. In its first 8 months of business, about 70 per cent of more than 2,000 tests have been for immigration cases, which on average involve fingerprinting blood samples from about five individuals.

Most cases involve a male resident in Britain applying for permission for his wife and children in Pakistan or Bangladesh to join him. According to $\mathrm{Mr}$ Ron Yaxley of Cellmark, the claimed relationships turn out to be accurate in about 95 per cent of cases, whereas only about 50 per cent of claims are validated by the traditional means of interviewing.

The pilot study of 40 immigration cases commissioned by the Home Office also shows that most claims are valid. The Home Office did query some of the results, says Yaxley, but they survived checking.

On the question of whether the test can always determine precise relationships, Yaxley and Jeffreys say that in the overwhelming majority of cases there is no problem, a point conceded by a Home Office spokesman last week in apparent contradiction of the minister's earlier statement.

Sorting out relationships is at its most difficult when, for example, some of the children claimed by a 'father' are in fact children of either his brother or his sisterin-law. It is easy to spot that they are not his, but not so easy to determine to which of his two relations they belong. The problem is resolved by new 'single locus probes', which complement those that determine variations in several chromosomal loci simultaneously.

Care must also be taken, says Jeffreys, to allow for new mutations - the extreme variability of certain DNA loci that accounts for the variations between individuals that are detected as DNA fingerprints is the result of a very high rate of mutation at the loci, so that a difference between a child and its two claimed parents may be the result of a new mutation rather than a false claim of parentage.

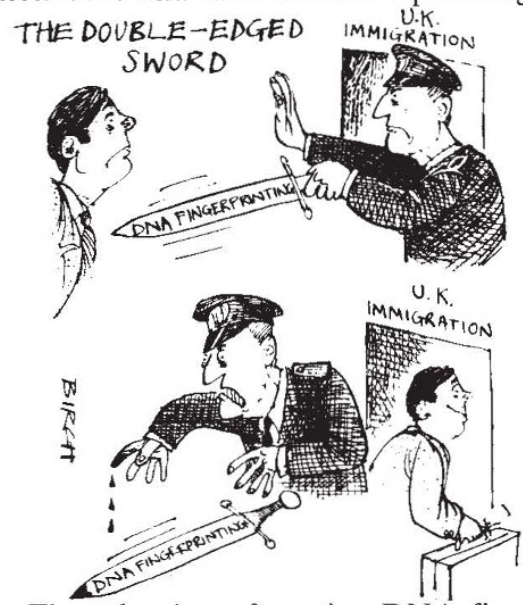

The adoption of routine DNA fingerprinting by immigration authorities has been urged by immigrants' organizations,

which believe it should speed up decisions and prevent many applications being wrongfully dismissed. The current system depends largely on interviews.

Dr David Pearl, who is a part-time adjudicator of disputed decisions, has pointed out in a recent article in The Law Society's Gazette that claims falsely made in other circumstances, perhaps for tax purposes, can come home to roost in subsequent immigration hearings. In particular, men falsely claiming wives and children who subsequently marry and sire children when visiting the sub-continent inevitably "get themselves into a horrible mess, and the whole application is almost bound to fail".

A Home Office decision on the adoption of routine testing is eagerly awaited by immigrants' organizations, who fear that it may be delayed by the political problems of approving a measure that increases immigration. Because the Home Office and the criminal courts have already approved the test in forensic cases, it is most unlikely that the test itself will be rejected for immigration cases. Moreover, for the purposes of the pilot study, the Home Office has already devised procedures to prevent the supply of false blood samples - blood has to be taken by an approved doctor under supervision in the British Embassy in Dacca or Islamabad, or by a consultant haematologist at a general hospital in Britain.

Whether the cost of testing will count against it in the Home Office's eyes remains to be seen. At an average testing cost of about $£ 500$ a case, Cellmark Diagnostics estimates an annual saving to the Home Office of $£ 7$ million, but Home Office costings are likely to differ.

Peter Newmark

\section{Mystery of bird deaths in Assam}

\section{New Delhi}

AN eight-year study by Indian zoologists has failed to establish why birds commit suicide year after year at the small village of Jatinga in the northeastern state of Assam.

Attracted by the lights, birds converge on Jatinga at night and on landing become immobile, stop feeding and starve. They neither resist capture nor try to fly away.

The peak suicide season is in September and October, when the Indian monsoon tapers off, and the place is always the same: a one-kilometre stretch between the railway station and the health centre. Knowing that birds are lured by lamps, the villagers light up the sky with Petromax lamps on tall bamboo poles to attract more birds, which are then barbecued and eaten.

The mysterious phenomenon has been occurring since 1905, according to Dr Sudin Sengupta of the Zoological Survey of India (ZSI), who launched a systematic scientific study in 1979 . Some 25 expeditions to
Jatinga have so far taken place but the Minister of Environment and Forests, $\mathrm{Mr}$ Z.R. Ansari, recently told parliament that "ZSI has not come to any conclusion as to the cause of the phenomenon."

Meanwhile, the state government of Assam has taken two steps to save the birds. Tall towers with powerful light sources have been erected to divert the birds from the light sources of Jatinga, and bird-watcher clubs have been formed to protect the dazed birds from villagers.

According to Sengupta, as many as $\mathbf{5 0 0}$ birds die every night during the peak season. Some 36 species of birds have been identified among the dead, including migratory birds. The studies have shown that the phenomenon, which takes place on dark rainy nights when winds are strong and clouds are dense, may be related to observed changes in geomagnetic and electric fields that apparently affect the bird's sense of orientation.
K.S. Jayaraman 